\title{
WYKORZYSTANIE URZĄDZEŃ NOKTOWIZYJNYCH W OKRESIE II WOJNY ŚWIATOWEJ PRZEZ NIEMIECKIE JEDNOSTKI PANCERNE
}

\begin{abstract}
Lotnictwo, które w Wielkiej Wojnie po raz pierwszy zastosowano do wykrywania wojsk przeciwnika oraz do ich obezwładniania, wymusiło nowe sposoby prowadzenia działań bojowych. Marsz dużych kolumn wojsk, który poza rubieżą styczności wojsk był wykonywany swobodnie, został narażony na obserwację i uderzenia lotnictwa. Wojsko rozpoczynało przemieszczanie się w strefie wojennej z reguły w nocy. O ile piechota w nocnych marszach radziła sobie w miarę swobodnie, o tyle czołgi i samochody ze względu na ciemność miały duże utrudniania. Aby zapewnić swobodne przemieszczanie się pojazdów mechanicznych w nocy opracowano urządzenia do obserwacji w nocy, zwane noktowizorami. Noktowizor to przyrząd elektroniczny umożliwiający widzenie obiektów w ciemności. Pierwsi badaniami i opracowaniem urządzeń do obserwacji w nocy zajęli się naukowcy niemieccy. Pierwsze urządzenia zastosowano w lotnictwie i artylerii przeciwlotniczej na przełomie 1941/42 roku. Kolejne urządzenia opracowano i zamontowano na czołgach typu Panthera. Badaniami i rozwojem urządzeń noktowizyjnych zajmuje się równolegle kilka zakładów produkcyjnych. Zamontowane urządzenia noktowizyjne na czołgach, wytypowanych jednostek, wykorzystane były w walkach wojsk niemieckich z aliantami. Niezależnie w tym samym okresie badaniami nad noktowizją zajmowali się naukowcy amerykańscy. Ich celem było opracowanie celownika noktowizyjnego dla karabinków. Pierwsze noktowizory zamontowano w USA na karabinkach M1, których w toku drugiej wojny światowej wyprodukowano i zamontowano 1700 sztuk. Podlegały one szczególnej ochronie.
\end{abstract}

Słowa kluczowe: noktowizor, Spanner I.

\section{WPROWADZENIE}

Sztuka wojenna od tysięcy lat poszukuje sposobów zaskoczenia przeciwnika po to, aby odnosić sukcesy i aby zwyciężać. „Od zawsze” starano się być „niewidzialnym” na polu walki. Początkowo dotyczyło to działań podejmowanych w nocy, czy nad ranem, kiedy przeciwnik zmożony nocnym czuwaniem spał. Później związane to było z użyciem odpowiedniego ubioru lub właściwego maskowania, które pozwalało zminimalizować możliwość wykrycia przez obserwatora. Dopiero w XX wieku rozpoczęły się badania, które miały nie tylko zminimalizować możliwość wykrycia, ale pozwalały widzieć w nocy, podobnie jak niektóre zwierzęta drapieżne, co w konsekwencji doprowadziło do badań nad noktowizją.

Noktowizja, to „dziedzina zastosowań techniki umożliwiającej widzenie w ciemności. Obserwacja różnych obiektów w ciemności może być realizowana przez wykorzystanie ich

\footnotetext{
${ }^{1}$ Gen. Fryderyk Czekaj, Politechnika Rzeszowska
} 
promieniowania własnego lub odbitego. W związku z tym przyrządy noktowizyjne dzieli się na pasywne i aktywne. Inny podział, uwzględniający zasadę pracy, rozróżnia przyrządy noktowizyjne elektronowo-optyczne i termograficzne. Podstawowym elementem przyrządu elektronowo-optycznego jest przetwornik elektronowo-optyczny, w którym dokonuje się zamiany obrazu utworzonego w niewidzialnym dla oka promieniowaniu podczerwonym na obraz widzialny. Termograficzny przyrząd do wykrywania i obserwacji ma detektor promieniowania podczerwonego, umieszczony w płaszczyźnie ogniskowej układu optycznego, urządzenie do poszukiwania pola cieplnego i układ do przetwarzania sygnałów elektrycznych, proporcjonalnych do intensywności strumienia promieniowania, w obraz widzialny"2.

Zgodnie z definicją zawartą w Encyklopedii techniki wojskowej, noktowizor to ,urządzenie optyczno-elektroniczne, umożliwiające obserwację terenu i obiektów w zakresie promieniowania podczerwonego bezpośrednio niewidocznego dla oka. Działanie noktowizora polega na wykorzystaniu promieniowania odbitego od otaczających przedmiotów, oświetlonych źródłem podczerwieni. Zasadnicze podzespoły noktowizora to źródło promieniowania podczerwonego $\mathrm{z}$ reflektorem (promiennikiem podczerwieni), służące do oświetlania terenu niewidzialnym dla oka promieniowaniem podczerwonym (detektor promieniowania podczerwonego), wykonany w postaci lornety, która spełnia rolę przetwornika elektronowo-optycznego (przetwornik podczerwieni) umożliwiającego przekształcanie odbitego od otaczających przedmiotów niewidzialnego promieniowania podczerwonego w obraz widzialny dla oka obserwatora oraz źródło prądu elektrycznego zasilające promiennik podczerwieni i przetwornik elektronowo-optyczny"3.

W podobny sposób definiowany jest noktowizor w Małej encyklopedii wojskowej. Wskazuje on, że noktowizor to ,przyrząd elektroniczny umożliwiający widzenie (obserwację) obiektów w ciemności. Zasada jego działania opiera się na wykorzystaniu promieniowania podczerwonego. Noktowizor składa się z trzech podzespołów: a) źródła promieniowania podczerwonego mającego postać reflektora oświetlającego teren niewidzialnym dla oka promieniowaniem podczerwonym, b) detektora promieniowania podczerwonego wykonanego w postaci lornety, która spełnia rolę przetwornika elektrooptycznego, umożliwiającego przekształcenie odbitego od przedmiotów otoczenia niewidzialnego promieniowania podczerwonego w obraz widzialny dla oka obserwatora, c) źródła prądu elektrycznego zasilającego reflektor i przetwornik elektrooptyczny"4.

Noktowizorem jest ,przyrząd elektroniczny umożliwiający widzenie (obserwację) obiektów w ciemności. Noktowizory są szeroko stosowane w technice wojskowej jako celowniki broni strzeleckiej oraz dział, jako urządzenie do skrytego prowadzenia w nocy pojazdów mechanicznych, do obserwacji terenu. Średni zasięg noktowizorów stosowanych jako celowniki broni strzeleckiej dochodzi do 300-400 m, a noktowizorów obserwacyjnych do $1000 \mathrm{~m} " 5$.

Jugend Lexikon Militarwesen definiuje noktowizor jako „techniczne urządzenie działające na bazie wykorzystania promieniowania podczerwonego, które jest wykorzystywane

\footnotetext{
2 S. Borkowski, Noktowizja [w:] Encyklopedia techniki wojskowej, red. Z. Mendygrał, Warszawa 1978, s. 421.

3 Ibidem, s. 421-422.

4 Noktowizor [w:] Mała encyklopedia wojskowa, red. M. Odlewany, t. 2, Warszawa 1978, s. 446.

5 Stownik podstawowych terminów wojskowych, Warszawa 1977, s. N-9.
} 
do dokładnego nocnego celowania uzbrojenia, a też prowadzenia pojazdów w nocy. Ich zasięg może wynosić około $1500 \mathrm{~m}$ "6.

Należy zaznaczyć, że stworzenie systemu noktowizyjnego związane było z zapewnieniem pojazdom wojskowym możliwości szybkiego i bezpiecznego przemieszczania się w nocy, szczególnie dlatego, że w dzień narażone były one na ataki lotnicze i dekonspirację dróg przemieszczania się i miejsc koncentracji. Ponadto wyposażone w takie urządzenia czołgi i inne pojazdy bojowe mogły atakować nieprzyjaciela w nocy, samemu będąc niewidzialnymi. Noktowizor pojazdu jest „,przyrządem obserwacyjnym czołgu, samochodu lub transportera opancerzonego umożliwiający obserwację przedpola i prowadzenie ognia z pojazdu w nocy. (...) Noktowizory pojazdów są na ogół noktowizorami typu aktywnego, a pojazd wyposażony jest $\mathrm{w}$ reflektor podczerwieni, oświetlający przedpole niewidzialnym dla oka promieniowaniem"7.

Współcześnie noktowizory są wykorzystywane w większości wozów bojowych, w tym w czołgach. Jako przykład niech posłuży projekt polskiego czołgu PT-91. Tworząc czołg PT-91 Twardy, wyposażono go w sprzęt noktowizyjny. W skład kompletu przyrządów obserwacyjnych wchodził pasywny noktowizor dowódcy POD-72. Także kierowca wyposażony został w stereoskopowy pasywny noktowizor PNK-72 „Radomka” o kącie obserwacji 30 stopni i znacznym współczynniku wzmocnienia światła. Jak pisze T. Szulc: „O jakości Radomki może świadczyć przypadek, jaki zdarzył się grupie konstruktorów z Łabęd, asystującej w poligonowych, nocnych strzelaninach Twardego. Wyszli oni na spotkanie czołgu, wracającego ze strzelnicy w pochmurną, bezksiężycową noc. Z daleka usłyszeli zbliżający się wóz. Ale nie mogli go dostrzec. Zdążyli nawet pomyśleć o ucieczce z drogi niewidocznemu kolosowi, gdy ten zatrzymał się o kilka kroków od nich. Okazało się, że kierowca widział ich doskonale i nie sądził, że jego wóz jest całkowicie niewidoczny w gęstym mroku"8.

Noktowizory są standardowym urządzeniem montowanym na czołgach I i II generacji ${ }^{9}$, jednak ich „czas dobiega końca”. Od III generacji stosowane są termowizyjne urządzenia obserwacyjno-celownicze, których istotą działania jest detekcja ciepła (wykorzystywane jest zjawisko fotoprzewodzenia) i przetwarzania obrazu termicznego w widzialny. Dzięki temu możliwe jest ich wykorzystanie nie tylko w nocy, ale także w innych warunkach ograniczonej widoczności, w tym we mgle, w warunkach dużego zadymienia, śnieżycy i ulewie $^{10}$.

Celem niniejszego opracowania jest zaprezentowanie podstawowej wiedzy na temat genezy urządzeń noktowizyjnych, a także ich wykorzystania ich w podstawowej wersji w broni pancernej.

6 U. Berger, W. Wunsche, Jugend Lexikon Militarwesen, Berlin 1984, s. 186.

S. Borkowski, Noktowizor [w:] Encyklopedia techniki wojskowej..., s. 422.

8 T. Szulc, Nowy polski czotg PT-91 Twardy, „Nowa Technika Wojskowa” 1993, nr 5, s. 2-3.

9 Patrz: I. Witkowski, Czotgi świata, Warszawa 1992; G. Forster, N. Paulus, Abriss der Geschichte der Panzerwaffe, Berlin 1982, s. 268-329.

10 D. Użycki, T. Begier, S. Sobala, Wspótczesne gąsienicowe wozy bojowe, Warszawa 1996, s. 49. 


\section{PRACE NAD URZĄDZENIEM NACHTSICHTGERATEN W NIEMCZECH W LATACH 1938-1945}

Urządzenia noktowizyjne były przedmiotem badań naukowych i prac koncepcyjnych w Niemczech od połowy lat trzydziestych. Zajmowały się tym firmy AEG, Mayer, Leitz, Zeiss, RPF (Reichspostforschungsanstalt). Ich prace koncepcyjne zaowocowały pojawieniem się na początku lat czterdziestych różnymi typami urządzeń noktowizyjnych, a w konsekwencji wykorzystaniem ich w działaniach bojowych w okresie 1944-1945.

Urządzenia noktowizyjne typu Spanner (Sp. I, II, IIa, IIb, III, IV), FG (1223, 1223a, 1223b, 1223c, 1250, 1251 Uhu, 1252, 1253, 1254, ), Falker (Falker R, II, III), ZG (ZG 1221, 1229 Vampir), Habicht, Mucke, produkowane przez poszczególne zakłady produkcyjne używane były zarówno do badań, jak i skierowane zostały do produkcji w celu ich wykorzystania w działaniach bojowych.

Jednym z urządzeń noktowizyjnych były produkty typu Spanner. Były to produkty firm AEG i Mayer o nazwie Spanner I (Sp.I), typu Bildwandler, o ogniskowej soczewki $\mathrm{f}=20 \mathrm{~cm}$ i promieniu obserwacji $12^{\circ}$, aktywnym zasięgu $300 \mathrm{~m}$ i pasywnym zasięgu do $10000 \mathrm{~m}$. Stosowano UR-Scheinwerfer o średnicy $330 \mathrm{~mm}$ i mocy od 100 do $1000 \mathrm{~W}$. Sp.I był wyprodukowany w małej serii w latach 1941-1942, testowany był w ośrodku doświadczalnym w Rechlinie, a jego przeznaczeniem było wyszukiwanie celów dla artylerii. Innym z urządzeń noktowizyjnych był produkt firm AEG i Leitz o nazwie Spanner II (Sp.II), będący pasywnym przyrządem obserwacyjnym typu Beobachtungsgerat (BG), oparty konstrukcyjnie na bazie urządzenia Bildwandler, o ogniskowej soczewki $\mathrm{f}=15 \mathrm{~cm}$, promieniu obserwacji 30 , o zasięgu do $14000 \mathrm{~m}$. Wyprodukowano go w 1941 roku i przeznaczono dla nocnych myśliwców Messerschmit 110. W późniejszym czasie był produkowany seryjnie i stosowany w artylerii przeciwlotniczej. Kolejnym urządzeniem był produkt firm AEG, Leitz i Zeiss o nazwie Spanner IIa (Sp.IIa) i Spanner IIb (Sp.IIb), który był pasywnym przyrządem obserwacyjnym typu Beobachtungsgerat (BG), na bazie Bildwandler, o ogniskowej soczewki $\mathrm{f}=9 \mathrm{~cm}$, promieniu obserwacji $30^{\circ}$, o zasięgu do $8000 \mathrm{~m}$. Był produkowany w dużej serii na bazie lampy typu 126 (trioda) i napięciu roboczym 17000 V. Następnym urządzeniem był produkt firm AEG, Leitz o nazwie Spanner III (Sp.III), który był pasywnym przyrządem obserwacyjnym typu Beobachtungsgerat (BG), na bazie Bildwandler, o ogniskowej soczewki $\mathrm{f}=15 \mathrm{~cm}$, promieniu obserwacji $18^{\circ}$ lub $30^{\circ}$, o zasiegu 14000 m. Był produkowany w 1942 roku. Ostatnim z nich był produkt firm AEG i Leitz o nazwie Spanner IV (Sp.IV). Był to prototyp pasywnego przyrządu obserwacyjnego w formie peryskopu na bazie urządzenia Bildwandler, przeznaczonego dla samolotów Dornier Do-215, o ogniskowej soczewki $\mathrm{f}=12,5 \mathrm{~cm}$, promieniu obserwacji $60^{\circ}$, wyprodukowany w 1943 $\mathrm{roku}^{11}$.

Kolejnym typem urządzeń noktowizyjnych były produkty typu FG. Pierwszy z nich to urządzenie FG 1223, będący produktem firm AEG, Leitz i Zeiss. Był to aktywny przyrząd obserwacyjny dla kierowców pojazdów typu Fahrgerat (FG), mający także właściwości celownika, oparty na konstrukcji Bildwandlera, o ogniskowej soczewki $\mathrm{f}=9 \mathrm{~cm}$ i promieniu obserwacji $30^{\circ}$, aktywnym zasięgu $400 \mathrm{~m}$ i pasywnym zasięgu do $8000 \mathrm{~m}$. Był produkowany seryjnie. Kolejnym urządzeniem był FG 1223a, będący także produktem firm AEG, Leitz i Zeiss. Był aktywnym przyrządem obserwacyjnym dla kierowców samochodów ciężarowych LKW, typu Fahrgerat (FG), oparty na konstrukcji Bildwandlera, o ogniskowej

\footnotetext{
11 W. Trojca, PzKpfw. V Panther, Vol. 2, Gdańsk 1999, s. 3-5.
} 
soczewki $\mathrm{f}=9 \mathrm{~cm}$ i promieniu obserwacji $30^{\circ}$, aktywnym zasięgu $400 \mathrm{~m}$ i pasywnym zasięgu do $8000 \mathrm{~m}$. Był rozwojową wersją poprzedniego typu, produkowany seryjnie. Następnym urządzeniem był FG 1223b, będący też produktem firm AEG, Leitz i Zeiss. Był to aktywny przyrząd obserwacyjny dla kierowców czołgów Panther, umieszczony w peryskopie, typu Fahrgerat (FG), oparty na konstrukcji Bildwandlera, o ogniskowej soczewki $\mathrm{f}=9 \mathrm{~cm}$ i promieniu obserwacji $30^{\circ}$, aktywnym zasięgu $400 \mathrm{~m}$ i pasywnym zasięgu do $8000 \mathrm{~m}$. Ponadto urządzenie UR-Scheinwerfer o średnicy $200 \mathrm{~mm}$ i mocy $200 \mathrm{~W}$, będące rozwinięciem urządzenia Spanner IIa. Był produkowany seryjnie. Następnym z nich był produkt tych samych firm, typu FG 1223c. Był to aktywny przyrząd obserwacyjny oraz celowniczy dla dowódców czołgów, umieszczony w wieżyczce obserwacyjnej czołgów Panther, typu Fahrgerat (FG), oparty na konstrukcji Bildwandlera, o ogniskowej soczewki $\mathrm{f}=9 \mathrm{~cm}$ i promieniu obserwacji $30^{\circ}$, aktywnym zasięgu $400 \mathrm{~m}$ i pasywnym zasięgu do $8000 \mathrm{~m}$. Ponadto urządzenie UR-Scheinwerfer o średnicy $200 \mathrm{~mm}$ i mocy 200W, będące rozwinięciem urządzenie Spanner IIa. Był produkowany seryjnie. Innym urządzeniem był aktywny przyrząd obserwacyjny i celowniczy dla dowódcy czołgu Panther-FG 1250, produkt firm AEG i Leitz. Był on mocowany do wieżyczki obserwacyjnej dowódcy. Zbudowany na bazie konstrukcji Bildwandlera, o ogniskowej soczewki $\mathrm{f}=9 \mathrm{~cm}$ i promieniu obserwacji $30^{\circ}$, aktywnym zasięgu $400 \mathrm{~m}$ i pasywnym zasięgu do $8000 \mathrm{~m}$. Był sprzężony z urządzeniem UR-Scheinwerfer o średnicy $200 \mathrm{~mm}$ i mocy $200 \mathrm{~W}$. Był produkowany seryjnie. Urządzenie FG 1250 było także instalowane do podstawy karabinu maszynowego MG 34 w czołgach Panther i MG 42 w transporterach Sd.Kfz 251. Podobny przyrząd był instalowany w transporterze opancerzonym Sd.Kfz 251 przed wziernikiem kierowcy. Kolejnym urządzeniem był aktywny przyrząd obserwacyjny montowany na transporterze opancerzonym Sd.Kfz 251/20 Uhu - FG 1251 Uhu. Był produktem firm AEG i Leitz, w którym zastosowano węglową lampę łukową UR-Scheinwerfer o średnicy $600 \mathrm{~mm}$ i mocy $6 \mathrm{~kW}$. Zbudowany na bazie konstrukcji Bildwandlera, o ogniskowej soczewki $\mathrm{f}=40 \mathrm{~cm}$ i promieniu obserwacji $4,5^{\circ}$, aktywnym zasięgu $1500 \mathrm{~m}$ i pasywnym zasięgu do $15000 \mathrm{~m}$. był umieszczony w transporterze opancerzonym na obrotowej podstawie. Był produkowany seryjnie, przy czym do końca wojny ukończono budowę 60 zestawów Uhu, a dalsze 600 było w różnych fazach produkcji. Następnym był aktywny przyrząd obserwacyjny dla kierowcy w zestawie Falke, dla transportera Sd.Kfz 251 - FG 1252, będący produktem firm AEG, Leitz, RPF, Zeiss. Był rozwinięciem urządzeń FG 1250, FG 1223a, $1223 \mathrm{~b}, 1223 \mathrm{c}$. Był produkowany seryjnie. Kolejnym był aktywny przyrząd obserwacyjny dla kierowców ciężarówek, a także czołgów Panther działający na zasadzie peryskopu, typu FG 1253, będący produktem firm AEG, Leitz, RPF, Zeiss, produkowanym seryjnie. Ostatnim z tych urząazeń był aktywny przyrząd obserwacyjny dla kierowców czołgów Panther działający na zasadzie peryskopu - FG 1254, będący produktem firm AEG, Leitz, RPF, Zeiss. Był produkowany seryjnie ${ }^{12}$.

Produkowane były także pasywne urządzenia obserwacyjne Falter. Były produkowane przez firmy AEG, Leitz, RPF. Były to pasywne przyrządy obserwacyjne typu Beobachtungsgerat (BG), oparty konstrukcyjnie na bazie urządzenia Bildwandler, o ogniskowej soczewki $f=7,5 \mathrm{~cm}$. Ponadto urządzenia obserwacyjne Falter R, Falter II i Falter III, o ogniskowej soczewki $\mathrm{f}=5 \mathrm{~cm}$, produkowane przez firmy Leitz i RPF. Były produkowane w krótkiej serii ${ }^{13}$.

\footnotetext{
12 Ibidem, s. 5-12.

13 Ibidem, s. 6-7.
} 
Należy zaznaczyć, że celowniki noktowizyjne były przedmiotem prac badawczych od wielu lat. Już w 1936 roku niemiecki Herreswaffenamt WaPruf 8 polecił firmie AEG rozpoczęcie prac nad urządzeniami obserwacyjnymi i celownikami noktowizyjnymi. Prace nad pierwszym takim urządzeniem ukończono w 1939 roku. Doświadczalnie zostało zamontowane na armacie przeciwpancernej Pak 36 kalibru $37 \mathrm{~mm}$. Próby wykazały wiele usterek, lecz jednocześnie praktycznie potwierdziły możliwość używania promieni podczerwonych do wykrywania celów w nocy ${ }^{14}$. W 1942 roku zbudowano udany celownik dla armaty przeciwpancernej Pak 40, który wyposażony był w reflektor UR typu ZG 1221 o średnicy $36 \mathrm{~cm}^{15}$. Urządzenie działało w ten sposób, że cel musiał być najpierw „oświetlony” wiązką promieni podczerwonych wysyłanych ze „specjalnego” reflektora. Po oświetleniu celu mógł być użyty celownik noktowizyjny FG $1250^{16}$. Do 1944 roku wykonano 1000 takich urządzeń, lecz dowództwo niespodziewanie zakazało ich używania. W drugiej połowie 1944 roku Niemcy zdecydowali się jednak na użycie urządzeń noktowizyjnych. Urządzenie działało na zasadzie pasywnej. „Reflektor” (Infrarot-Schneiwerfer) wysyłał w kierunku celu wiązki promieni podczerwonych, które „oświetlały” cel i wracały do urządzenia odbiorczego (Bildwandler), gdzie były przetwarzane na obraz widzialny ${ }^{17}$. Podobne urządzenie zamontowane zostało na dziale samobieżnym Marder II, wyposażonym w armatę przeciwpancerną Pak $40^{18}$.

W tym czasie produkowano i używano trzech typów urządzeń celowniczych Zielgerat ZG 1128, 1221, 1222, urządzeń do kierowania pojazdami w nocy Fahrgerat FG 1250, 1252, 1253 oraz urządzenia obserwacyjnego 1251. Czołgi Panther wyposażone były w urządzenie Sperber A, składającego się z reflektora o średnicy $30 \mathrm{~cm}$ i mocy $200 \mathrm{~W}$ oraz urządzenia przetwarzającego. Urządzenie to zamontowane było na wieży czołgu na specjalnej podstawie zamontowanej na wierzchu włazu dowódcy. Pod koniec wojny używano także urządzenia wersji Sperber B, który dodatkowo składał się z urządzenia przetwarzającego, montowanego z przodu kadłuba, na stanowisku kierowcy i dodatkowo na stanowisku celowniczego. Czołgi z noktowizorami posiadały generatory GG 400 zamontowane z tyłu przedziału bojowego (w miejscu parku amunicyjnego, służące do przetwarzania prądu o napięciu $17000 \mathrm{~V}$ do transformatora HS 5F urządzenia przetwarzającego. Urządzenia te montowane były w zakładach MNH w Hanowerze. We wrześniu 1944 roku zamontowano 20 urządzeń noktowizyjnych, a w październiku tego roku już $80^{19}$.

Powstały zestaw noktowizyjny, zamontowany w czołgu Panther, posiadał reflektor o średnicy $20 \mathrm{~cm}$, emitujący promieniowanie podczerwone, które niewidoczne było dla oczu człowieka, a także w przyrząd obserwacyjno-celowniczy o powiększeniu 1,2 raza. Takie dobór niewielkiego powiększenia wynikał z faktu, że zadaniem dowódcy czołgu było nie tylko wyszukiwanie celów, ale także wskazywanie drogi kierowcy, który był pozbawiony podobnego urządzenia. Dla oddania skutecznego strzału dowódca czołgu musiał umieścić znak celowniczy na niszczonym obiekcie, a dzięki układowi mechanicznemu informacja o wymaganym kącie podniesienia armaty trafiała do działonowego. Zasięg efektywnej pracy urządzenia wynosił około $100 \mathrm{~m}$. Mimo tak niskich właściwości urządzeń

\footnotetext{
14 J. Ledwoch, PzKpfw. V Sd.Kfz 171 Panther, Warszawa 1998, s. 22.

15 W. Trojca, $P z K p f w . V$ Panther, Vol. 2..., s. 7.

16 J. Ledwoch, PzKpfw. V Panther..., s. 14-16.

17 J. Ledwoch, PzKpfw. V Sd.Kfz 171 Panther, Warszawa 1998, s. 22.

18 W. Trojca, PzKpfw. V Panther, Vol. 2..., s. 7.

19 J. Ledwoch, PzKpfw. V Sd.Kfz 171 Panther..., s. 24.
} 
noktowizyjnych w czołgach w stosunku do pojazdów współczesnych, użycie ich dawało ogromną przewagę nad przeciwnikiem, który nie dysponował podobnym urządzeniem. Istotne jest także to, że poczynione zostały także kroki mające na celu wyposażenia w urządzenia noktowizyjne także kierowców pojazdów i strzelców karabinów maszynowych na transporterach opancerzonych. Widać w tym było dążenie do podjęcia nocnych działań przez kompletne zespoły składające się z czołgów, wspierających je transporterów opancerzonych i piechoty, a działających $\mathrm{w}$ zespole $\mathrm{z}$ samobieżnym reflektorem podczerwieni na bazie transportera Sdkfz. 251/20 Uhu ${ }^{20}$.

Należy zaznaczyć, że w zakresie używania noktowizorów na wozach bojowych, Niemcy byli prekursorami ich skonstruowania i zastosowania na większą skale. Ich pionierskie wykorzystanie w czołgach Panther wraz z zestawem Sdkfz. 251/20 zdeterminowało myśl techniczną innych krajów do zastosowania tego wynalazku w późniejszym czasie, stając się podstawą standaryzacji tego wyposażenia we wszystkich liczących się armiach świata. Pierwszeństwo niemieckiej myśli technicznej w tym zakresie jest bezsporne, chociaż podobne badania $\mathrm{z}$ wykorzystaniem prototypowych okularowych noktowizorów prowadzono w Wielkiej Brytanii, wyposażając w 1943 roku czołgi typu Churchill, Cavalier, Centaur.

\section{WYKORZYSTANIE URZĄDZEŃ NOKTOWIZYJNYCH W WALKACH W OKRESIE 1944-1945}

Zestawy noktowizyjne zamontowano przede wszystkim na czołgach typu PzKpfw. V Panther G. Planowano także wyposażyć w standardowe urządzenia tego typu nowo konstruowane czołgi typu Panther Ausf. F i Panther II ${ }^{21}$. Istnieje też prawdopodobieństwo, że zestaw noktowizyjny planowany był do zamontowania w superciężkim czołgu E- $100^{22}$.

Według J. Ledwocha czołgi z noktowizorami wykorzystane były w szerokim zakresie. Trafiały one do różnych jednostek bojowych w drugiej połowie 1944 roku. Czołgi wyposażone w urządzenia noktowizyjne trafiły między innymi do 3. szwadronu 24 DPanc (z uwagi na to, że 24 . DPanc powstała z 1 . DKawalerii jej pododdziały nosiły nazwy kawaleryjskie ${ }^{23}$. Jak wspominał jeden z żołnierzy 1. Pułku Pancernego SS 1. DPanc SS LSSAH, kilka czołgów wyposażonych w urządzenie noktowizyjne było używanych w jednostce na przełomie 1944/1945 roku. Czołgi były używane bojowo podczas ofensywy w Ardenach ${ }^{24}$. Jeden z czołgów wraz z pojazdem SdKfz. 251/20 walczył na terenie Węgier w marcu 1945 roku. W lutym 1945 roku 1. kompania 101. Batalionu Panc. przydzielona do Fuhrer Grenadier Division prowadziła testy bojowe urządzeń noktowizyjnych. Kompania miała przy-

${ }^{20}$ D. Użycki, T. Begier, S. Sobala, Wspótczesne gąsienicowe wozy bojowe, Warszawa 1996, s. 48-49.

21 T.J. Lenz, H.L. Doyle, Panzerkampfwagen Panther II and Panther Ausfuchrung F, Publisher Darlington Productions Inc., Darlington 2006, s. 50-53; J. Ledwoch, PzKpfw. V Panther..., WarszawaHannower-Speyer 1993, s. 13-14.

22 T.J. Lenz, H.L. Doyle, Schwere Panzerkampfwagen Maus and E-100, Publisher Darlington Productions Inc., Darlington 2008, s. 50; M. Lewandowski, Pancerny kolos Hitlera - czotg superciężki E-100, "Militaria. Ilustrowany Magazyn Historyczny" - wydanie specjalne 2014, nr 4, s. 81-85; W. Trojca, German Secret Panzer Projects, Katowice-Speyer 2005, s. 59-69.

23 J. Ledwoch, PzKpfw. V Sd.Kfz 171 Panther..., s. 24.

${ }^{24}$ J. Ledwoch, PzKpfw. V Panther..., s. 16. 
dzielone trzy transportery z urządzeniami obserwacyjnymi Beobachtergerat 1251. Ponadto czołgów z urządzeniami FG 1250 używały 1. batalion 6. Pułku Panc., a także 130. Pułku Panc., jak i 4. kompania 11. Pułku Panc. ${ }^{25}$.

Czołgi wyposażone w systemy noktowizyjne z 11. pułku pancernego 6. Dywizji Pancernej walczyły wiosną 1945 roku z jednostkami 3. Armii pod dowództwem gen. G.S. Pattona $^{26}$.

W kwietniu 1945 roku Dywizja Pancerna „Clausewitz” (z Ausbildung Lehrgang Fallingbostel) znalazła się na drodze XIII Korpusu US Army, który nacierał w kierunku na Berlin, tracąc w walkach większość gąsienicowych wozów bojowych, w tym czołgi wyposażone w systemy noktowizyjne ${ }^{27}$.

W kwietniu w ramach Dywizji Pancernej „Munchenberg” wykorzystano czołgi Panther $\mathrm{z}$ noktowizorami nad Odrą ${ }^{28}$. Była to jedna $\mathrm{z}$ jednostek niemieckich, przystosowanych do działań nocnych II./Pz.Abt. Muncheberg, dowodzona przez majora Rolfa Marquarda. Posiadała 10 czołgów typu Panther Ausf. G, wyposażonych w celowniki na podczerwień typu Sperber FG1250, którym był pojedynczy reflektor o średnicy $30 \mathrm{~cm}$ i o zasięgu $600 \mathrm{~m}$, a także konwerter obrazu sterowany przez dowódcę. Czołgi wspomagane były przez wyposażoną w noktowizory kompanię grenadierów pancernych na transporterach opancerzonych, którymi były 3 pojazdy typu Sdkfz. 251/20 Uhu z reflektorami $60 \mathrm{~cm}$, przeznaczonymi do współdziałania z czołgami Panther i z 3 transporterami opancerzonymi Sdkfz. 251/21 Falke ${ }^{29}$.

Na początku kwietnia 1945 roku zdecydowano się na wprowadzenie formacji do działań nocnych pod Reitwein. Kompania czołgów wyposażona w czołgi Panther z noktowizorami pod dowództwem oberleutnanta Rasima oraz transportery z noktowizorami, pod dowództwem hauptmanna Steuera i leutnanta Draegera przepuściła atak na pozycje wojsk sowieckich. Był to jeden z pierwszych przypadków użycia noktowizji w walce, a nocny atak, mimo że był mocno ograniczony, uznany został za sukces, mimo tego, że dokładne wyniki użycia jednostki wyposażone w systemy noktowizyjne nie są znane, zauważają G-U. Herrmann i U. Klr ${ }^{30}$. Należy uznać, że zbliżający się koniec wojny uniemożliwił szersze wykorzystanie tego wyposażenia w oddziałach pancernych, a także jego jednoznacznej oceny.

Należy przy tym zaznaczyć, że wraz z czołgami Panther współdziałały transportery półgąsienicowe. Transporter opancerzony Sdkfz. 251/20 Uhu, określony mianem Infrarotscheinwerfer - Panzerkampfwagen, to wersja wyposażona w reflektor podczerwieni nazwana Uhu (Sowa). Budowana w niewielkiej ilości na podwoziu wersji Sd.Kfz.251 auf. D, posiadała reflektor podczerwieni o średnicy $60 \mathrm{~cm}$, wraz z urządzeniami generującymi. Pojazd ten przeznaczony był do współpracy z pododdziałami czołgów PzKpfw. V Panther G, wyposażonych w noktowizory w celu wyszukiwania i podświetlania celów w nocy. Kierowca

25 J. Ledwoch, PzKpfw. V Sd.Kfz 171 Panther..., s. 24.

${ }^{26}$ T. Jarmoła, Za wschodnia granica Rzeszy... Działania amerykańskiej 3. Armii w Czechostowacji w 1945 roku, ,Militaria. Ilustrowany Magazyn Historyczny” - wydanie specjalne 2014, nr 2, s. 91.

${ }^{27}$ P. Langenfeld, Przyczótek na Łabie. US Army podchodzi pod Berlin, „Militaria. Ilustrowany Magazyn Historyczny" - wydanie specjalne 2013, nr 6, s. 44-46.

28 T. Anderson, V. Wal, Panther, Hongkong 1996, s. 63-66.

${ }^{29}$ P. Krukowski, Panzer Division Muncheberg. Bój o twierdzę Kostrzyn, „Militaria” 2016, nr 3(49), s. 65 .

${ }^{30}$ G-U. Herrmann, U. Klr, Der Schlüssel für Berlin: Hintergründe, Vorbereitung und Verlauf der Schlacht um die Seelower Höhen, Verlag Helios, Aachen 2010, s. 139-140. 
Sdkfz. 251/20 Uhu także był wyposażony w peryskop na podczerwień, umożliwiający obserwację oświetlanego terenu. Miał on zamontowany mały noktowizor umożliwiający orientację w nieznanym terenie w nocy. Ponadto pojazd mógł mieć zamontowany noktowizor na swoim uzbrojeniu ochronnym $(\mathrm{km} \text {-ie })^{31}$. Należy zaznaczyć, że transportery Sd.Kfz.251 Uhu w trakcie wspólnej akcji z czołgami Panther „oświetlały” teren, przekazywały informację o wykrytych celach do czołgów Panther, a te niszczyły cele, nawet z odległości około $800 \mathrm{~m}$, same nie będąc widzianymi przez przeciwnika ${ }^{32}$.

\section{ZAKOŃCZENIE}

W zakończeniu należy zaznaczyć, że znaczące podwaliny w rozwój systemów noktowizyjnych położyli Niemcy, tworząc całe spektrum urządzeń, montowanych w pojazdach, w tym samochodach, czołgach, transporterach opancerzonych, a też w uzbrojeniu strzeleckim i wykorzystanych w działaniach bojowych w latach 1944-1945.

Wykorzystane w systemy noktowizyjne wozy bojowe faszystowskich Niemiec odnosity sukcesy o znaczeniu lokalnym, nie mogąc w żaden sposób odwrócić losów wojny, niemniej jednak stworzone na początku lat czterdziestych urządzenia mogły w znaczący sposób zmienić taktykę prowadzenia działań bojowych, pozwalając na atakowanie przeciwnika także w nocy, a także na przemieszczanie się nocą, bez obawy wykrycia przez przeciwnika.

Nie bez znaczenia jest też informacja, że prowadzone badania w innych armiach, w okresie wojny w zasadzie nie wyszły poza fazę prototypów, chociaż Amerykanie skupili się na badaniach nad celownikiem noktowizyjnym. Ważnym etapem rozwoju amerykańskiego karabinka M1 było przystosowanie go do montowania celownika noktowizyjnego $\mathrm{T} 120^{33}$. Jego zmodyfikowana wersja nosiła nazwę T3, a wyprodukowano ich 1919 sztuk. Należy przy tym zaznaczyć, że w trakcie wojny Amerykanie opracowali trzy wersje noktowizorów do tej broni. Pierwszy z nich Sniperscope T120 opracowany był w 1943 roku, miał aktywny zasięg około $120 \mathrm{~m}$, a oświetlane cele były barwy zielonej. W roku 1943 wersja ta została standaryzowana i wprowadzona na wyposażenie pod oznaczeniem Sniperscope M1. Kolejna wersja pod nazwą Sniperscope M2 miał aktywny zasięg około $100 \mathrm{~m}$. Łącznie w czasie wojny wyprodukowano 1700 egzemplarzy noktowizorów T120, M1, M2, a ich wykorzystanie było limitowane klauzulą ,tajne" ${ }^{34}$. Karabiny M1 wraz z noktowizorami, na szeroką skalę, wykorzystane zostały w maju i czerwcu 1945 roku na Okinawie, przyczyniając się do znaczących strat wroga, poniesionych od ognia broni strzeleckiej ${ }^{35}$.

Urządzenia noktowizyjny wykorzystane były na dużą skalę dopiero po II wojnie światowej, przy czym na szerszą skalę używane były od lat sześćdziesiątych w czołgach II generacji. W czołgach tych wykorzystywane były urządzenia, których zasięg nie przekraczał 100 m, a w czołgach III generacji mógł przy świetle księżyca sięgać 2500 m, a w świetle gwiazd $1500 \mathrm{~m}$.

${ }^{31}$ W. Rogowski, Transporter opancerzony Sdkfz. 251, cz. III, Małe Monografie nr 6, Łódź 1993, s. 1.

32 W. Trojca, PzKpfw. V Panther, Vol. 2..., s. 9.

${ }^{33}$ L. Erenfeicht, Karabinek M1 i jego amunicja 7,62x33’, „Mundur i Broń” 2000, nr 2, s. 13-16.

${ }^{34}$ T. Piątkowski, Rozwój broni strzeleckiej w czasie II wojny światowej - karabinki na nabój pośredni, „Militaria. Ilustrowany Magazyn Historyczny” - wydanie specjalne 2009, nr 4, s. 7.

35 R.S. Rush, U.S. Infantryman In World War II. Pacific Area of Operations 1941-45, Osprey Publishing, Oxford 2002, s. 53-60. 


\section{LITERATURA}

[1] Anderson T., Wal V., Panther, Concord Published, Hongkong 1996.

[2] Berger U., Wunsche W., Jugend Lexikon Militarwesen, MilitarVerlag, Berlin 1984.

[3] Borkowski S., Noktowizja [w:] Encyklopedia techniki wojskowej, red. Z. Mendygrał, Wydawnictwo MON, Warszawa 1978.

[4] Borkowski S., Noktowizor [w:] Encyklopedia techniki wojskowej, red. Z. Mendygrał, Wydawnictwo MON, Warszawa 1978.

[5] Forster G., Paulus N., Abriss der Geschichte der Panzerwaffe, MilitarVerlag, Berlin 1982.

[6] Herrmann G-U., Klr U., Der Schlüssel für Berlin: Hintergründe, Vorbereitung und Verlauf der Schlacht um die Seelower Höhen, Verlag Helios, Aachen 2010.

[7] Jarmoła T., Za wschodnia granica Rzeszy... Dziatania amerykańskiej 3 Armii w Czechostowacji w 1945 roku, ,Militaria. Ilustrowany Magazyn Historyczny” - wydanie specjalne 2014, $\mathrm{nr} 2$.

[8] Krukowski P., Panzer Division Muncheberg. Bój o twierdzę Kostrzyn, „Militaria” 2016, $\mathrm{nr} 3(49)$.

[9] Langenfeld P., Przyczótek na Łabie. US Army podchodzi pod Berlin, „Militaria. Ilustrowany Magazyn Historyczny" - wydanie specjalne 2013, nr 6.

[10] Ledwoch J., PzKpfw. V Panther, Wydawnictwo Militaria, Warszawa 1992.

[11] Ledwoch J., PzKpfw. V Panther, Wydawnictwo Militaria, Warszawa-Hannower-Speyer 1993.

[12] Ledwoch J., PzKpfw. V Sd.Kfz 171 Panther, Wydawnictwo Militaria, Warszawa 1998.

[13] Lenz T.J., Doyle H.L., Panzerkampfwagen Panther II and Panther Ausfuchrung F, Publisher Darlington Productions Inc., Darlington 2006.

[14] Lenz T.J., Doyle H.L., Schwere Panzerkampfwagen Maus and E-100, Publisher Darlington Productions Inc., Darlington 2008.

[15] Lewandowski M., Pancerny kolos Hitlera - czotg superciężki E-100, „Militaria. Ilustrowany Magazyn Historyczny" - wydanie specjalne 2014, nr 4.

[16] Noktowizor [w:] Mała encyklopedia wojskowa, red. M. Odlewany, t. 2, Wydawnictwo MON, Warszawa 1978.

[17] Piątkowski T., Rozwój broni strzeleckiej w czasie II wojny światowej - karabinki na nabój pośredni, „Militaria. Ilustrowany Magazyn Historyczny” - wydanie specjalne 2009, nr 4.

[18] Rogowski W., Transporter opancerzony Sdkfz. 251, cz. III, „Małe Monografie” nr 6, GPM, Łódź 1993.

[19] Rush R.S., U.S. Infantryman In World War II. Pacific Area of Operations 1941-1945, Osprey Publishing, Oxford 2002.

[20] Stownik podstawowych terminów wojskowych, MON, Sztab Generalny WP, Warszawa 1977.

[21] Szulc T., Nowy polski czotg PT-91 Twardy, „Nowa Technika Wojskowa” 1993, nr 5.

[22] Trojca W., German Secret Panzer Projects, Wydawnictwo PP Model Hobby, Katowice-Speyer 2005.

[23] Trojca W., PzKpfw. V Panther, Vol. 2, TankPower, AJ-Press, Gdańsk 1999.

[24] Użycki D., Begier T., Sobala S., Wspótczesne gąsienicowe wozy bojowe, Wydawnictwo Lampart, Warszawa 1996.

[25] Witkowski I., Czotgi świata, Wydawnictwo WIS, Warszawa 1992. 


\section{THE USE OF NIGHT VISION DEVICES IN THE WORLD WAR II BY GERMAN PANZER UNITS}

The aviation, used for the first time in the Great War to detect and overpower the enemy forces, forced the new ways of conducting combat activities. The marching of large columns of militaries, which was conducted freely away from the borders, was endangered by observation and air strike. Militaries began to move within the war zone at night, as a rule. While the infantry did quite well in marching at night, tanks and vehicles faced certain difficulties due to the darkness. To enable motor vehicles free movement at night, devices for observing objects at night, called night vision devices, were developed. A night vision device is an electronic device enabling observing objects at night. It was German scientists who as first dealt with the research and development of the devices for conducting observation at night. First devices were used in the aviation and anti-aircraft artillery, between 1941 and 1942. The next device was developed and installed in the Panthera tank. A few manufacturers simultaneously worked on the research and development of night vision devices. The night vision devices installed on tanks of selected units were used in fights between German and Allied troops. Independently, at the same time American scientists conducted research on night vision. They aimed at developing night vision sight for carbines. The first night vision devices were installed in the USA on M1 carbines, produced and installed in the amount of 1700 pieces during the WWII. They were subject to a special protection.

Keywords: Night vision device, Spanner I. night observation.

DOI:10.7862/rz.1017.hss.16

Przestano do redakcji: luty $2017 \mathrm{r}$.

Przyjęto do druku: czerwiec 2017 r. 
